\title{
Co-composting of Olive Mill Waste and Wine-Processing Waste: An Application of Compost as Soil Amendment
}

\author{
Z. Majbar (D), ${ }^{1}$ K. Lahlou, ${ }^{1}$ M. Ben Abbou, ${ }^{2}$ E. Ammar, ${ }^{3}$ A. Triki, ${ }^{4}$ W. Abid, ${ }^{3}$ M. Nawdali, \\ H. Bouka, ${ }^{2}$ M. Taleb, ${ }^{1}$ M. El Haji, ${ }^{6}$ and Z. Rais ${ }^{1}$ \\ ${ }^{1}$ Laboratory of Engineering, Electrochemistry and Modeling Environment (LEEME), Faculty of Sciences, Fez, Morocco \\ ${ }^{2}$ Laboratory of Natural Resources and Environment, University Sidi Mohammed Ben Abdallah, Faculty Polydisciplinary, \\ Taza, Morocco \\ ${ }^{3}$ Research Unity: Urban and Costal Environments, University of Sfax, National Engineering School of Sfax, Sfax, Tunisia \\ ${ }^{4}$ Research Laboratory: Improvement and Protection of Olive Tree Genetic Resources, Institute of the Olive Tree, \\ Sfax BP1087, Tunisia \\ ${ }^{5}$ Laboratory of Chemistry of Condensed Matter (LCCM), University Sidi Mohammed Ben Abdallah, \\ Faculty of Sciences and Technology, Fez, Morocco \\ ${ }^{6}$ Laboratory Engineering Research-OSIL Team Optimization of Industrial and Logistics Systems, University Hassan II, \\ Superior National School of Electricity and Mechanic (ENSEM), Casablanca, Morocco
}

Correspondence should be addressed to Z. Majbar; zinebmajbar@gmail.com

Received 4 May 2018; Revised 22 July 2018; Accepted 8 August 2018; Published 23 September 2018

Academic Editor: Gassan Hodaifa

Copyright $\odot 2018$ Z. Majbar et al. This is an open access article distributed under the Creative Commons Attribution License, which permits unrestricted use, distribution, and reproduction in any medium, provided the original work is properly cited.

In order to decrease the environmental harm produced by the agro industries' wastes', an investigation of the co-composting of olive mill waste (olive mill wastewater (OMW), olive mill sludge (OMS)) and wine by-products (grape marc and winery wastewater) was done. Three aerated windrows of variable compositions were performed; these windrows differ in terms of their initial composition and the liquid used for their humidification; OMW and wastewater winery were used for humidification to replace water for windrow moistening. Moreover, the main physicochemical parameters (temperature, $\mathrm{pH}$, electrical conductivity, and $\mathrm{C} / \mathrm{N}$ ) were monitored to evaluate the co-composting process. The latter lasted around three months. The elaborated composts were characterized by low $\mathrm{C} / \mathrm{N}$ ratio, and they were rich in fertilizing and nutriment elements and of low heavy metal contents. The humidification of the windrows with OMW showed effectiveness in improving the windrows temperature, reflected by the high temperatures monitored during the composting process in comparison with the windrow humidified with winery wastewater. Furthermore, a longer thermophilic phase was held in windrows carrying OMS. The valorization of the produced composts for soil amendment significantly improved the soil fertility. Indeed, field experiments showed an increase in radish yield by $10 \%$, the composts were harmless and did not have any phytotoxic effect on radish growth.

\section{Introduction}

The activity of the agro-food industries causes a lot of harm to environment due to the production of huge amounts of waste. In Morocco, the industrial sector generates yearly more than 1.2 million tons of wastes, among which the agrofood industry represents $67 \%$ [1]. Consequently, the management and the valorization of these harmful residues are necessary for the environment"s preservation.
The olive oil extraction is an important activity that generates a huge amount of effluent, namely, olive mill wastewater, estimated to $400000 \mathrm{~m}^{3}$ per year [2]. The OMW is an acidic and dark liquid effluent, with a high organic matter load and high conductivity [3,4]; its composition varies both qualitatively and quantitatively according to the olive variety, climate condition, cultivation and harvesting practices, the olive storage time, and the olive oil extraction system [3]. 
In Morocco, the OMW management practice regulated and adopted by the majority of olive oil industries is the storage in evaporation ponds. However, this technique does not reduce the OMW toxicity since large quantities of olive mill sludge (OMS) are produced. These huge quantities represent a significant problem in olive oil industries; therefore, more effective solutions must be developed to remedy this problem.

The wine industry is another activity that generates significant quantity of waste; this activity produces large amount of by-products that are represented by solid organic residues (grape marc) and wastewater. The production of one hectoliter of wine produces $18 \mathrm{~kg}$ of grape marc [5], which gives an annual production of 7200 tons [6]. Still, the quantity of wine wastewater depends largely on the process used in the industry. The different residues from the wine industry are characterized by low $\mathrm{pH}$ and electrical conductivity and high organic matter content [7]. The richness of these by-products in organic matter allows their use for soil fertility improvement $[8,9]$. The direct incorporation of these residues could cause serious environmental problems if they are added excessively to the soil in an uncontrolled manner. Consequently, their treatment is crucial before their discharge or use for agricultural purposes. The suitable management of these agro-food wastes is an important strategy for the environment protection. Many investigations have focused on the study of treatment and valorization techniques of these residues at an experimental scale [10-16]. At the industrial level, the treatment of these residues is rare, and the problem of all the available wastes has not yet been solved.

Recently, researchers have shown that composting is one of the effective alternatives for the recycling and the valorization of organic wastes $[8,17-22]$. It is a degradation process of the organic matter, allowing the achievement of a stable product, rich in humic substances and in fertilizing elements, serving as soil organic amendment [23-25]. The application of compost can have strong ecological environmental values, allowing not only the removal of very expensive chemical fertilizers but also the improvement of the quality of agricultural soils and carbon sequestration $[8,9,26]$.

Diverse studies had developed composting of organic waste, such as OMW $[19,24,27-30]$, sludge from wastewater treatment [31], and agro-industrial waste [32]. While other studies on the co-composting of olive mill wastewater with poultry manure $[25,27,33]$, olive mill wastewater with solid organic waste $[20,34]$, and date palm with activated sludge [35] have been carried out. The evaluation of the composting process and the study of its environmental impact due to gas emissions have also been the subject of numerous studies [35-38].

Considering the fact that co-composting olive oil waste (OMW and OMS) and wine industry have not gained much attention in previous studies; the aims of this work are as follows: firstly, to valorize the olive mill wastes (OMW and OMS) and by-products wine industry by co-composting; secondly, to study the evolution of the parameters describing the co-composting of mixtures of OM, OMS, and green waste; and lastly, to test the effect of the different composts produced on the performance and yield of radish in the field.

\section{Materials and Methods}

2.1. Raw Materials. The organic wastes used as substrates for the composting procedure included OMW, OMS, grape marc, winery wastewater, and household waste. The OMW and OMS were collected from a natural evaporation basin of continuous three-phase olive oil extraction unit located in Meknassa Ben Ali ( $8 \mathrm{~km}$ form Taza, Morocco). The basin was made of concrete with a storage capacity of $240 \mathrm{~m}^{3}$. The collected OMW had a maximum storage time of 30 days; the OMS were collected at the end of August, after a total evaporation of the quantities of water contained in the OMW. The grape marc and the winery wastewater were collected from an industrial company "Celliers de Meknès" located in Meknes (Morocco), and the green waste was gathered from markets located in Taza (Morocco). They are composed mainly of fruit and vegetable residues. The waste physicochemical characterization is presented in Table 1.

2.2. Composting Procedure. The raw materials were mixed in order to be co-composted in open area, using 3 windrows of $0.6 \mathrm{~m}$ height, $2 \mathrm{~m}$ length, and $1.2 \mathrm{~m}$ diameter base [30]. These windrows differed in terms of their initial composition and the liquid used for their humidification (Table 2). The proportions of the raw materials were calculated according to the methods described by Proietti et al. and Soudi $[26,39]$ to obtain a physicochemical characterization of the initial mixture for starting the composting process.

The moisture content was adjusted to around 50-60\% (optimal moisture content for composting); this operation was performed during the turning of the windrows. The windrows were turned once every 3 days at the beginning of the process, then once every 7 days, and once every 15 days for the remaining composting period.

Representative and homogenous samples were collected during the composting procedure from the windrows for analysis. Each sample was obtained by mixing 6 subsamples taken from six different points of windrows, according to ISO 8633 [40].

2.3. Physicochemical Analysis. The raw materials and compost samples were analyzed for $\mathrm{pH}$ and electrical conductivity (EC) in a $1: 5(\mathrm{w} / \mathrm{v})$ water soluble extract in $[41,42]$. The dry matter content was assessed by drying at $105^{\circ} \mathrm{C}$ for $24 \mathrm{~h}$ using a drying oven type WTB Binder ED 115, and the $\mathrm{OM}$ was determined by measuring the loss of ignition at $550^{\circ} \mathrm{C}$ for $4 \mathrm{~h}$ using muffle furnace type Lenton EF11/8B. The organic carbon (OC) was calculated using the following equation:

$$
\mathrm{CO}(\%)=\frac{\% \mathrm{MO}}{1,724}
$$

The total Kjeldahl nitrogen (TKN) was analyzed using the Kjeldahl method according to AFNOR standard (1981) [43]. The determination of heavy metals and oligoelements were first extracted by heating $2 \mathrm{~g}$ of compost with $\mathrm{HNO}_{3}$, and then the filtrate was analyzed using ICP-AES method (inductively coupled plasma atomic emission spectroscopy). 
TABle 1: Physicochemical characteristics of the raw materials used for composting process.

\begin{tabular}{|c|c|c|c|c|c|}
\hline Parameters & OMS & OMW & Grape marc & Winery wastewater & Green waste \\
\hline $\mathrm{pH}$ & $5.42 \pm 0.03$ & $5.43 \pm 0.05$ & $7.42 \pm 0.20$ & $6.66 \pm 0.02$ & $5.88 \pm 0.02$ \\
\hline $\mathrm{EC}\left(\mathrm{mS} \cdot \mathrm{cm}^{-1}\right)$ & $8.72 \pm 0.02$ & $8.02 \pm 0.02$ & $4.81 \pm 0.03$ & $0.76 \pm 0.02$ & $1.63 \pm 0.02$ \\
\hline Moisture (\%) & $22.66 \pm 3.69$ & $92.47 \pm .0 .56$ & $72.42 \pm 0.58$ & $99.86 \pm 0.01$ & $36.98 \pm 4.59$ \\
\hline Dry matter (\%) & $77.34 \pm 3.69$ & $7.53 \pm 0.56$ & $27.58 \pm 0.58$ & $0.14 \pm 0.01$ & $63.02 \pm 4.59$ \\
\hline Mineral matter (\%) & $15.05 \pm 5.91$ & $25.25 \pm 5.46$ & $30.19 \pm 1.65$ & $45.20 \pm 6.63$ & $35.15 \pm 1.95$ \\
\hline Organic matter (\%) & $84.95 \pm 5.91$ & $74.75 \pm 5.46$ & $69.81 \pm 1.65$ & $54.80 \pm 6.63$ & $64.85 \pm 1.95$ \\
\hline Organic carbon (\%) & $49.28 \pm 3.43$ & $43.36 \pm 3.16$ & $40.49 \pm 0.96$ & $31.78 \pm 3.84$ & $37.61 \pm 1.13$ \\
\hline TKN (\%) & $0.74 \pm 0.12$ & $0.86 \pm 0.15$ & $0.97 \pm 0.10$ & $3.75 \pm 0.30$ & $1.53 \pm 0.06$ \\
\hline $\mathrm{C} / \mathrm{N}$ & $67.77 \pm 9.73$ & ND & $42.06 \pm 3.47$ & ND & $24.69 \pm 1.19$ \\
\hline $\operatorname{COD}\left(\mathrm{g} \cdot \mathrm{O}_{2} / \mathrm{l}\right)$ & ND & $96.07 \pm 0.5$ & ND & $14.07 \pm 0.1$ & ND \\
\hline $\mathrm{BOD}\left(\mathrm{g} \cdot \mathrm{O}_{2} / \mathrm{l}\right)$ & ND & $25.67 \pm 0.51$ & ND & $14.40 \pm 0.4$ & ND \\
\hline
\end{tabular}

ND: not determined.

TABle 2: Composition of the different windrows.

\begin{tabular}{lccc}
\hline Windrow & $\begin{array}{c}\mathrm{A} \\
(600 \mathrm{~kg})\end{array}$ & $\begin{array}{c}\mathrm{B} \\
(600 \mathrm{~kg})\end{array}$ & $\begin{array}{c}\mathrm{C} \\
(1 \mathrm{ton})\end{array}$ \\
\hline $\begin{array}{l}\text { Proportion of solid raw } \\
\text { materials* }\end{array}$ & & & \\
$\quad$ (i) OMS & $1 / 3$ & $1 / 3$ & 0 \\
$\quad$ (ii) Grape marc & $1 / 3$ & $1 / 3$ & $1 / 2$ \\
$\quad$ (iii) Green waste & $1 / 3$ & $1 / 3$ & $1 / 2$ \\
Humidification effluent & $\mathrm{OMW}$ & Winery & $\mathrm{OMW}$ \\
Total volume used $\left(\mathrm{m}^{3}\right)$ & 0.8 & wastewater & \\
\end{tabular}

${ }^{*}$ Proportion expressed in weight/weight.

The characterization of the effluents was performed according to the experimental protocols described by Rodier et al. [44]. $\mathrm{pH}$ and electrical conductivity were directly measured using multiparameter consort C335. The chemical oxygen demand (COD) was determined according to NF T90-101 standard [45]. The biological oxygen demand (BOD) was determined using BOD meter-type OxiTop.

The windrow temperature was measured using multiparameter consort C535 daily during the mesophilic and the thermophilic composting phases and weekly until its maturity. The presented temperature value consists of a mean of 6 measurements at different points and depths of the windrow.

2.4. Phytotoxicity Test. The compost phytotoxicity was determined by evaluating its aqueous extract on seed germination. The germination test was carried out on 10 seeds of cress (Lepidium sativum) experimented at different dilutions in Petri dishes, including filter paper soaked in the compost extract. The test was conducted in dark at $25^{\circ} \mathrm{C}$ for 72 hours $[32,33]$. Three repetitions were performed.

The germination index (GI) was determined considering the number of sprouts and root growth, using the following equation:

$$
\mathrm{GI}(\%)=\frac{\mathrm{GB}}{\mathrm{GT}} * \frac{\mathrm{LB}}{\mathrm{LT}} * 100,
$$

where GB is the number of germinated seeds in the case of aqueous extract, GT is the number of germinated seeds in the case of the control where the distillated water was used, LB is the root length on compost extract, and LT is the root length control.

2.5. Radish Production. The effects of the different produced composts were assessed on radish (Raphanus sativus), of a National variety. Nine parcels of $1.5 \mathrm{~m}^{2}$ arranged in a random design were tested using compost and different combinations of compost mixed with farm manure, according to Table 3. These various combinations of composts and manure were used for the soil amendment at a rate of $6 \mathrm{t} / \mathrm{ha}$; they were incorporated in the soil not only spread on the surface. The parcel, which was only amended with farm manure, was considered as the control. No mineral fertilization has been done in the parcels.

The radish seeds were sowed on 29 November 2015, and the radish was harvested on 24 January 2016. The composts effects were assessed by measuring radish yield at the end of the crop cycle.

2.6. Statistical Analysis. Statistical analyses of data were made by IBM SPSS Statistics Version 20. The analysis of the means comparison was carried out by Student's $t$-test to compare the evolution profiles of the composting parameters for the different windrows. The Duncan test was used to calculate the variance and to compare the average values of germination indices for the different composts produced.

All analyses were performed in triplicate. However, for agronomic yields, the results were obtained in the form of one replicate due to the limitation of the plots to a single field. Also, minerals and fertilizing elements and heavy metals were in only one replicate because of the limited cost of investigation of the analysis.

\section{Results and Discussion}

\subsection{Composting Process}

3.1.1. Temperature Evolution. During the composting process, the evolution of the temperature in the different windrows is presented in Figure 1. The temperature profiles allow the observation of four conventional stages: a mesophilic, a thermophilic, a cooling, and a maturation stage. 
TABLE 3: Treatments used for parcel amendment.

\begin{tabular}{lcccccccccc}
\hline Parcel & $\mathrm{P}_{0}$ & $\mathrm{P}_{1}$ & $\mathrm{P}_{2}$ & $\mathrm{P}_{3}$ & $\mathrm{P}_{4}$ & $\mathrm{P}_{5}$ & $\mathrm{P}_{6}$ & $\mathrm{P}_{7}$ & $\mathrm{P}_{8}$ & $\mathrm{P}_{9}$ \\
\hline $\begin{array}{l}\text { Compost (\%) } \\
\text { Compost type }\end{array}$ & 0 & 100 & 100 & 100 & 75 & 75 & 75 & 50 & 50 & 50 \\
$\begin{array}{l}\text { Farm manure } \\
(\%)\end{array}$ & & $\mathrm{C}_{\mathrm{A}}$ & $\mathrm{C}_{\mathrm{B}}$ & $\mathrm{C}_{\mathrm{C}}$ & $\mathrm{C}_{\mathrm{A}}$ & $\mathrm{C}_{\mathrm{B}}$ & $\mathrm{C}_{\mathrm{C}}$ & $\mathrm{C}_{\mathrm{A}}$ & $\mathrm{C}_{\mathrm{B}}$ & $\mathrm{C}_{\mathrm{C}}$ \\
\hline
\end{tabular}

$\mathrm{C}_{\mathrm{A}}, \mathrm{C}_{\mathrm{B}}$, and $\mathrm{C}_{\mathrm{C}}$ are the different mature composts prepared, respectively, from the windrows $\mathrm{A}, \mathrm{B}$, and $\mathrm{C}$.

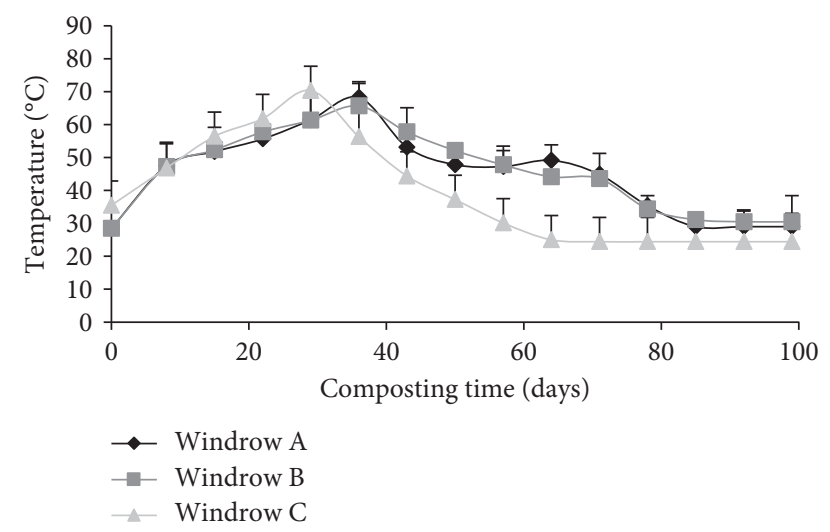

Figure 1: The windrows' temperature profiles during the composting process.

In the first stage, an increase of the temperature to $47^{\circ} \mathrm{C}$ was recorded during the first week. This observation resulted from the rapid colonization and activity of the mesophilic microorganisms, which degraded organic matter and released heat, thus increasing the windrows' temperature. Then, the temperature rose progressively to reach values above $60^{\circ} \mathrm{C}$, corresponding to the second stage, the thermophilic phase, and remained approximately 6 weeks. This result was due to the intense microbial activity reflecting high degradation rates occurring during the first stage [20]. The high temperatures may result in the reduction of pathogens and enhanced windrow sanitation [18]. At the 6th week, the third stage began, and the temperature decreased progressively to reach $30^{\circ} \mathrm{C}$. These low temperatures were the result of the less intense microbial activity due to the depletion of easily degradable organic matter [21]. Finally, at the maturity stage, the temperature stabilized at $30^{\circ} \mathrm{C}$, the process of composting reached its end, and the produced compost was mature. Moreover, the windrow temperature was highly related to the ambient temperature at this stage.

The long phases observed in windrows $\mathrm{A}$ and $\mathrm{B}$ can be attributed to the initial composition of the mixtures, in particular the presence of OMS. Indeed, the OMS presents a source of organic matter and therefore an availability of additional degradable substances in these mixtures (windrows $\mathrm{A}$ and $\mathrm{B}$ ) contrary to mixture $\mathrm{C}$. Hachicha et al. have found the similar results suggesting that the self-insulating capacity of OMS during the degradation process can lead to a long thermophilic phase [27]. Such a phase reflects an abnormal degradation process and a delayed transition to the stabilization phase [46].
Additionally, these results also show a significant difference between the temperature profile of windrows $A$ and $\mathrm{C}$ and windrows $\mathrm{B}$ and $\mathrm{C}$, confirmed by the means comparison test by Student's $t$-test $(p<0.05$. This difference can be attributed to the activity of microorganisms during the degradation process depending on the initial composition of the substrates.

3.1.2. $\mathrm{pH}$ Evolution. The $\mathrm{pH}$ evolution of the composted materials followed the same trend in the different windrows (Figure 2). At the beginning of the process, a slight decrease in $\mathrm{pH}$ was noted. This result could be explained by the production of organic acids, dissolved $\mathrm{CO}_{2}$ in the medium and by-products from the degradation of easily biodegradable compounds [46]. Then, an increase in $\mathrm{pH}$ from 6.5 to 6.7 , from 6.44 to 6.59 , and from 6.48 to 7.66 was observed for windrows A, B, and C, respectively. This could be the result of ammonia production from the degradation of amines [35, 47]. Finally, the $\mathrm{pH}$ decreased progressively and stabilized at a neutral $\mathrm{pH}$ for windrows $\mathrm{A}$ and $\mathrm{B}$ and alkali $\mathrm{pH}$ for $\mathrm{C}$. These results suggest the formation of humic substances which act as buffers, as confirmed by Zenjari et al. and Amir et al. [48, 49].

The comparison between the three $\mathrm{pH}$ profiles shows a significant difference $(p<0.05)$ between windrows $\mathrm{A}$ and $\mathrm{C}$ and windrows $B$ and $C$. This can be explained by the nature of the initial substrates put to compost. However, the addition of OMW during the composting process influences the $\mathrm{pH}$ of the mixtures.

3.1.3. EC Evolution. The progress of the electrical conductivity (EC) during the composting process is presented in Figure 3. During the first weeks of composting process, the EC values increased from 2.11 to $3.42 \mathrm{mS} \cdot \mathrm{cm}^{-1}$, from 2.04 to $3.95 \mathrm{mS} \cdot \mathrm{cm}^{-1}$, and from 2.09 to $3.87 \mathrm{mS} \cdot \mathrm{cm}^{-1}$, respectively, in the windrows $\mathrm{A}, \mathrm{B}$, and $\mathrm{C}$. This increase revealed the extent of mineralization of the organic substrate and the release of ions [35]. Then, a progressive decrease in the EC was observed, even in windrows moistened by OMW exhibiting salts loss by the leaching phenomenon as well as by decreasing their extractability because of their fixation on the stabilized organic matter [49].

Moreover, the EC was measured on the extract of organic matter which is sensitive to the solvent extraction ratio and the temperature at which the method was carried out. It could be noticed that each windrow composition presented a particular progress, with significant differences attributed to phenomena of mineralization, leaching, and fixation depending on the composition of the substrates and the activity of microorganisms.

3.1.4. Organic Matter Degradation. The evolution of the organic matter content of the mixture during the composting process is considered as an essential parameter of biodegradation and transformation of organic matter during composting. Figure 4 presents the organic matter contents of the three mixtures at the beginning and end of the 


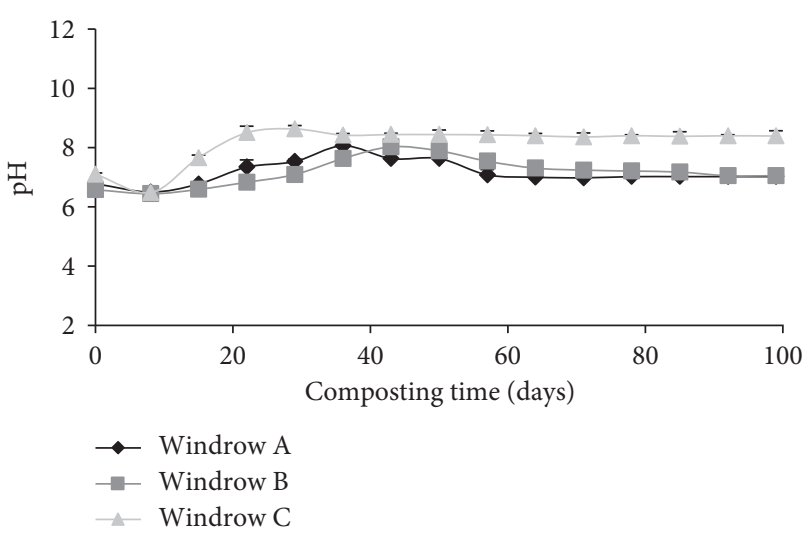

Figure 2: pH evolution during the composting process.

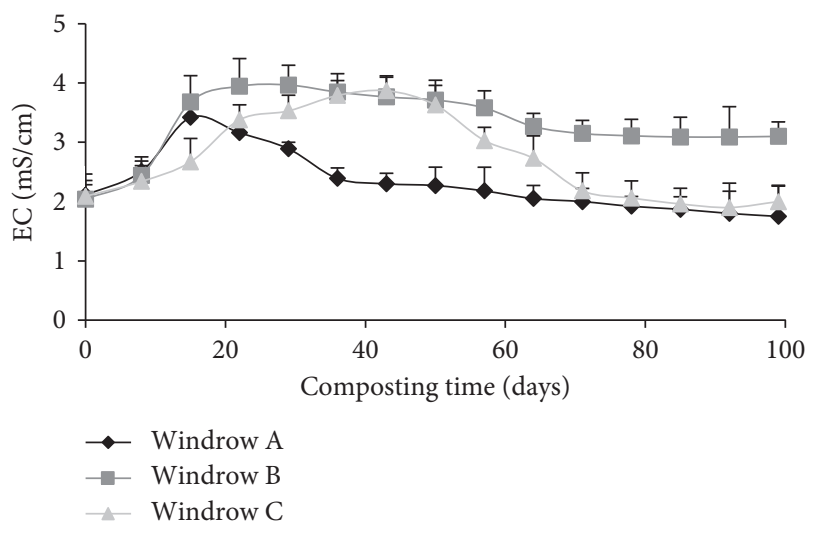

Figure 3: EC evolution during the composting process.

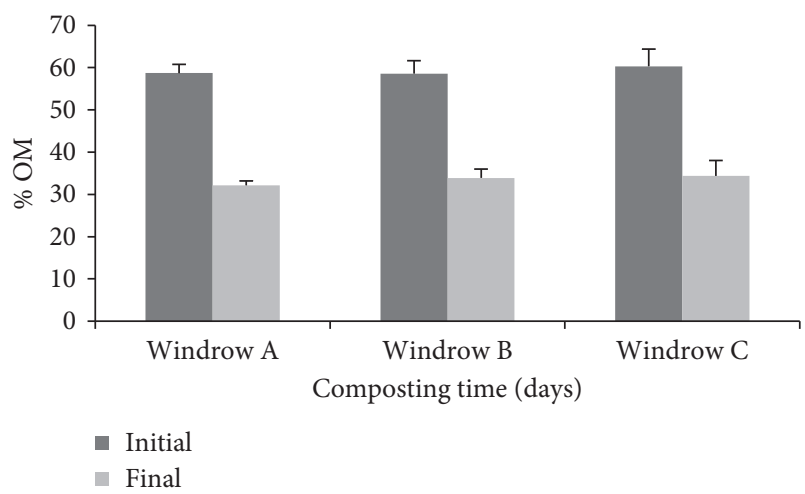

Figure 4: Organic matter degradation during the composting process.

composting process. These results show that all the experimented windrows were characterized by a high rate of organic matter $(>55 \%)$ at the beginning of the composting process. It could be noticed that the windrow $\mathrm{C}$ has the highest organic content. During the composting process, the organic matter content gradually decreased, resulting in a degradation rate exceeding $40 \%$ for the three mixtures.

This degradation is highlighted during composting by a mass loss of the initial mixtures or even a remarkable reduction in the volumes of co-composted waste. The organic matter decomposition was the result of the microbial activity, allowing the transformation of the organic matter into stable humic substances [50]. The similar results were observed by El Fels et al., indicating a good degree of compostability of the mixtures [35].

Furthermore, no significant difference was shown by Student's $t$-test between the three windrows. So, one can conclude that the degradation of organic matter does not depend on the composition or nature of the co-composted waste.

3.1.5. $\mathrm{C} / \mathrm{N}$ Ratio Evolution. The evolution of the $\mathrm{C} / \mathrm{N}$ ratio is directly related to the biodegradation of organic matter, resulting in the lowering of the total carbon rate associated with the increase in nitrogen concentration. The initial $\mathrm{C} / \mathrm{N}$ for the three windrows represented values between 25 and 35 (Figure 5). These $\mathrm{C} / \mathrm{N}$ ratios were ideal for co-composting process $[26,51]$. The $\mathrm{C} / \mathrm{N}$ ratio evolution showed decreases of the ratios from 27.7 to 12.0 , from 34.5 to 13.45 , and from 34.3 to 12.2 for the windrows $\mathrm{A}, \mathrm{B}$, and $\mathrm{C}$, respectively (Figure 5). This is closely related to the loss of organic carbon due to mineralization of the organic material, with a $\mathrm{CO}_{2}$ production increasing the nitrogen concentration in the windrows during the biodegradation.

At the end of the co-composting, the $\mathrm{C} / \mathrm{N}$ ratio reached values exceeding 8 for all windrows, indicating the maturity of the final compost [52]. Moreover, according to many authors, the $\mathrm{C} / \mathrm{N}$ ratio is considered to be a maturity index; generally, the compost is mature if it presents a $\mathrm{C} / \mathrm{N}$ ratio less than 20 [53-55].

The three profiles of the $\mathrm{C} / \mathrm{N}$ ratio evolution are of the same speed and represent no significant difference between the three windrows confirmed by Student's $t$-test $(p>0.05)$.

\subsection{Maturity and Quality of the Produced Composts}

3.2.1. Characterization of the Produced Composts. The quality of the composts was assessed by comparing the final characteristics of the conceived composts to those of the French standard NF U44-051 (Table 4). The composts produced were neutral, except compost $\mathrm{C}$ was characterized by alkaline $\mathrm{pH}$. This result is attributed to the nature of the co-composted waste. Also, they were characterized by $\mathrm{C} / \mathrm{N}$ ratio around 12 , exhibiting their stability.

The comparison of the three produced composts to the French standard showed significant amendment properties. Indeed, the produced composts were rich in fertilizing and mineral elements and low contents of heavy metals. These results have the same meaning with other previous studies valorizing OMW by co-composting, and the produced composts showed significant properties of organic fertilizers compared with the manure $[18,53,56]$.

3.2.2. Phytotoxicity. The phytotoxicity of the produced composts was evaluated by the germination test; the result of this test is shown in Figure 6. This figure revealed the effects 


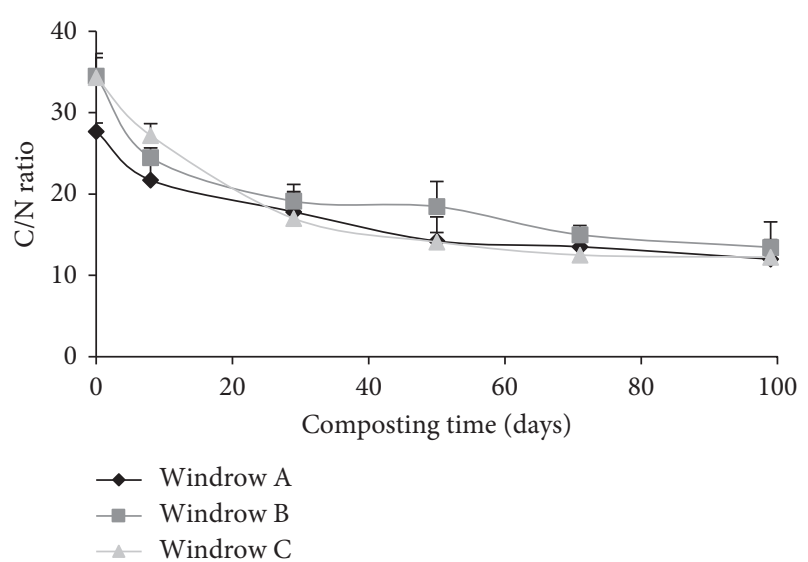

FIgUre 5: The $\mathrm{C} / \mathrm{N}$ ratio evolution during the composting process.

TABle 4: Physicochemical characteristics of produced composts.

\begin{tabular}{lcccc}
\hline Parameters & Compost A & Compost B & Compost C & NF U44-051 \\
\hline $\mathrm{pH}$ & $7.02 \pm 0.02$ & $7.09 \pm 0.03$ & $8.30 \pm 0.02$ & $\mathrm{ND}$ \\
$\mathrm{CE} \mathrm{mS} \cdot \mathrm{cm}^{-1}$ & $1.75 \pm 0.02$ & $3.04 \pm 0.03$ & $1.92 \pm 0.03$ & $\mathrm{ND}$ \\
$\mathrm{C} / \mathrm{N}$ & $12.00 \pm 1.23$ & $13.45 \pm 2.08$ & $12.24 \pm 1.15$ & $>8$ \\
\hline Minerals and & fertilizing & elements $(\mathrm{mg} / \mathrm{kg})$ & & \\
$\mathrm{P}$ & 855.99 & 158.37 & 346.15 & $\mathrm{ND}$ \\
$\mathrm{K}$ & 2763.56 & 2368.35 & 2264.55 & $\mathrm{ND}$ \\
$\mathrm{Mg}$ & 897.68 & 901.90 & 810.35 & $\mathrm{ND}$ \\
$\mathrm{Ca}$ & 10153.95 & 9237.85 & 9760.55 & $\mathrm{ND}$ \\
$\mathrm{Fe}$ & 5414.84 & 5101.55 & 6121.70 & $\mathrm{ND}$ \\
$\mathrm{Na}$ & 225.67 & 259.65 & 309.45 & $\mathrm{ND}$ \\
$\mathrm{Mn}$ & 49.65 & 31.65 & 33.35 & $\mathrm{ND}$ \\
\hline $\mathrm{Heavy}$ metals & $(\mathrm{mg} / \mathrm{kg})$ & & & \\
$\mathrm{Zn}$ & 57.83 & 11.6 & 12.2 & 600 \\
$\mathrm{Cu}$ & 22.26 & 5.95 & 6.55 & 300 \\
$\mathrm{Cr}$ & 9.35 & 7.60 & 5.95 & 12 \\
$\mathrm{Ni}$ & $<0.01$ & 0.06 & 0.06 & 2 \\
$\mathrm{Cd}$ & 1.5 & 1.0 & 1.2 & 3 \\
$\mathrm{As}$ & $<0.01$ & $<0.01$ & $<0.01$ & 18 \\
$\mathrm{Se}$ & $<0.01$ & $<0.01$ & $<0.01$ & 12 \\
\hline
\end{tabular}

ND: not determined.

of the extracts from produced composts on the germination of cress seeds at different dilutions.

The comparison between the different dilutions shows that a dilution rate of $25 \%$ shows the best germination for the different composts produced, marked by a higher rate for the compost and a significant difference between the different compost products C. However, a dilution rate of $50 \%$ shows a nonsignificant effect between the different compost products, whereas a dilution of $75 \%$ and the crude extract shows significant effects whose compost $\mathrm{C}$ represents the best germination index.

These differences can be explained by the nature of the raw materials, by the germination conditions of the watercress seeds and by the high conductivity of the compost extract. Indeed, high values in electrical conductivity inhibit the germination of watercress seeds, which results in low germination indices in raw compost extracts. According to
Lasaridi et al., compost that is too saline can be harmful to plants; acceptable EC values should not exceed 2 to $3 \mathrm{mS} / \mathrm{cm}$ [57]. However, the three composts do not represent any phytotoxic effect because all these results showed a germination rate higher than $50 \%$, indicating a maturity of the compost produced $[38,58]$.

\subsubsection{Effect of the Produced Composts on Radish Production.}

The radish yields were assessed at the end of the crop cycle, while harvesting. The yields are presented in Figure 7. On farm manure, the yield was equal to $52.5 \mathrm{t} / \mathrm{ha}$, but on the other parcels amended with the composts, the yield ranged from $52.8 \mathrm{t} / \mathrm{ha}$ to $57.7 \mathrm{t} / \mathrm{ha}$. The produced composts significantly improved the productivity of the radish crop. However, the highest yields remained in parcels amended with the composts obtained from windrows $\mathrm{C}$ and $\mathrm{A}$ of $10 \%$. It could be concluded that the OMW used for humidification played an important agronomic role. Indeed, the positive effect of composts based on olive mill waste on radish yields depends particularly on their richness in nutrients and fertilizers element particulates $\mathrm{N}, \mathrm{P}, \mathrm{K}, \mathrm{Ca}, \mathrm{Mg}$, and $\mathrm{Fe}[19,25]$. These elements play a very important role in the growth of plants, thus promoting their vegetative activity, which results in an improvement in radish production yield.

However, Regni et al. suggest that long-term application of composted OMW to the soil improves vegetative activity and olive yield. They confirm that the contribution of nutrients to composted olive mill waste through their amendments associated with other indirect factors such as organic and dynamic matter content, water retention, and microbial biomass activity stimulates olive tree growth and improves olive yield and quality. These results are consistent with those found by Hachicha et al. showing the significant effect of composts based on OMS and poultry manure on potato yield [27].

\section{Conclusion}

The co-composting of olive mill wastes and the wine byproducts with green waste has proved to be an effective means of producing an organic amendment for agricultural soils. The monitoring of the physicochemical parameters during this process has revealed a good progress of the cocomposting process, a biodegradation of organic matter and a bioconversion of unstable matter into a stable product rich in humic substances. This biotransformation was also confirmed by the phytotoxicity test of the compost extracts produced, which showed that the various composts produced are mature and show no phytotoxic effect.

Moreover, the physicochemical characterization has proved that these composts are of good quality, rich in nutrients and particularly $\mathrm{N}, \mathrm{P}, \mathrm{K}, \mathrm{Ca}, \mathrm{Mg}$, and $\mathrm{Fe}$, and conforms to the standards of an organic amendment NF U44-051. The application of compost produced in the fields as organic soil improvers for radish cultivation has had a positive effect by increasing radish production yield by $10 \%$ compared to manure. Given the slow and complex dynamics 


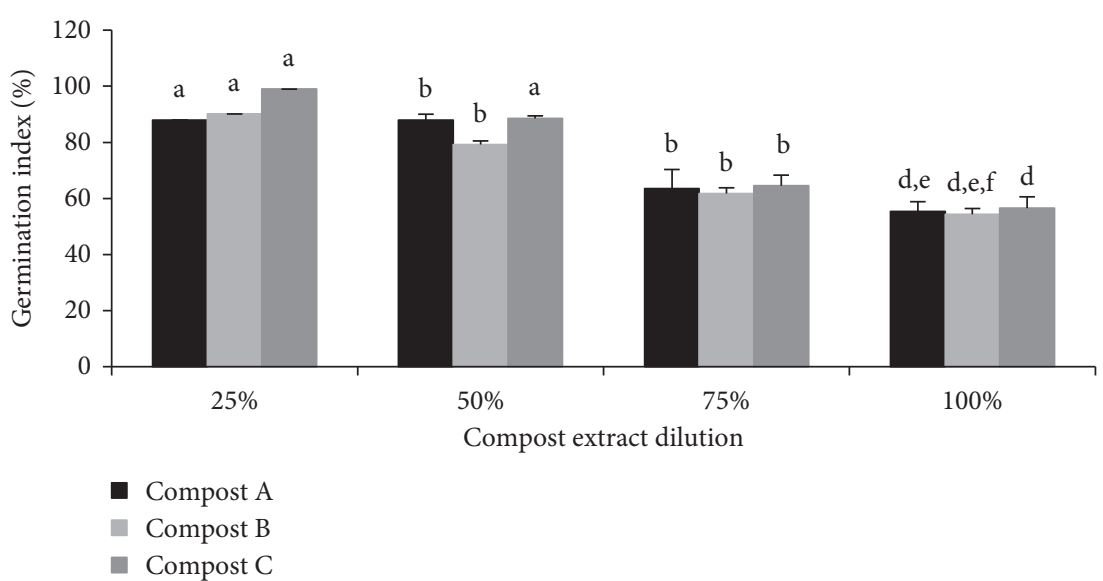

Figure 6: Effect of the compost extract on germination of cress seeds at different dilutions $(n=5, p=0.05)$. Different letters (a-f) indicate significant differences $(p<0.05)$ between compost and dilution rates.

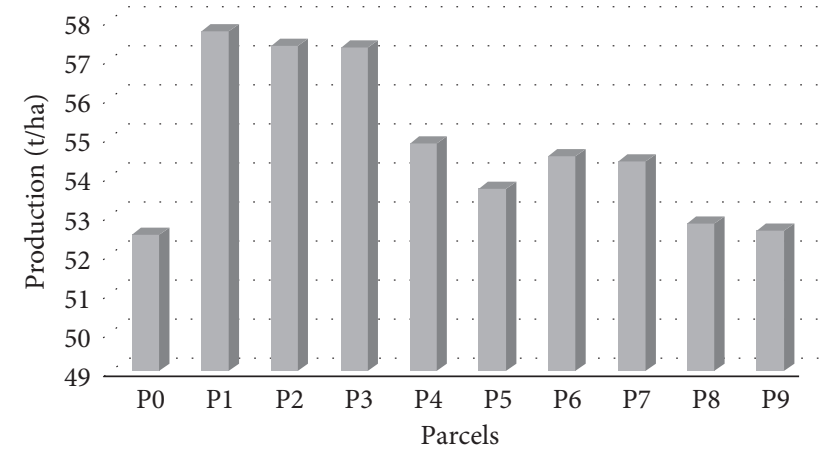

FIgURE 7: Production yield of harvested radish.

of organic substance transformation, long-term amendment experiments would be necessary and will be the subject of further research.

To conclude, one could say that the valorization of olive mill waste and the wine by-products is a promise strategy for the sustainable management of this type of waste allowing the transformation of environmental threats into a valuable product assuring fertility to agricultural soils.

\section{Data Availability}

The data used to support the findings of this study are available from the corresponding author upon request.

\section{Conflicts of Interest}

The authors declare that they have no conflicts of interest.

\section{Acknowledgments}

This work was supported by the funds of the PPR project type B (2015-2017) funded by the National Center for Scientific and Technical Research (CNRST). The authors would like to express their deep gratitude to all the professors and members of the doctoral research center who contributed to the improvement of this article. They extend their thanks to all of them for their advice, knowledge, insightful criticisms, and suggestions. Many thanks are also expressed to the persons who provided the material and made their laboratories available whenever needed.

\section{References}

[1] N. Perkins, A. Ajir, and L. El Ouazzani, Rapport sur la Gestion des Déchets Solides au Maroc, Scribd, San Francisco, CA, USA, 2014.

[2] M. Rahmani, Examen National de l'Export vert du Maroc: Produits Oléicoles, Romarin et Thym, United Nations, Geneva, 2017.

[3] S. Dermeche, M. Nadour, C. Larroche, F. Moulti-Mati, and P. Michaud, "Olive mill wastes: biochemical characterizations and valorization strategies," Process Biochemistry, vol. 48, no. 10, pp. 1532-1552, 2013.

[4] M. Ben Abbou, R. Rheribi, M. El Haji, Z. Rais, and M. Zemzami, "Effect of using olive mill wastewater by electrocoagulation process on the development and germination of tomato seeds," Physical and Chemical News, vol. 74, no. 10, pp. 37-43, 2014.

[5] Institut Français de la Vigne et de Vin, Marcs de Raisins, Lies de Vin et Bourbes : Quelle Gestion des Sous-Produits Vinicoles?, Institut Français de la Vigne et de Vin, Le Grau-du-Roi, France, 2013.

[6] Direction du Développement Des Filières de Production, Ministère de l'Agriculture, de la Pêche Maritime, du Développement Rural et des Eaux et des Forêts Rabat, 2016.

[7] M. A. Bustamante, R. Moral, C. Paredes, A. Pérez-Espinosa, J. Moreno-Caselles, and M. D. Pérez-Murcia, "Agrochemical characterisation of the solid by-products and residues from the winery and distillery industry," Waste Management, vol. 28, no. 2, pp. 372-380, 2008.

[8] L. Regni, L. Nasini, L. Ilarioni et al., "Long term amendment with fresh and composted solid olive mill waste on olive grove affects carbon sequestration by prunings, fruits, and soil," Frontiers in Plant Science, vol. 7, 2017.

[9] P. Proietti, E. Federici, L. Fidati et al., "Effects of amendment with oil mill waste and its derived-compost on soil chemical and microbiological characteristics and olive (Olea europaea L.) productivity," Agriculture, Ecosystems and Environment, vol. 207, pp. 51-60, 2015. 
[10] E. Bertran, X. Sort, M. Soliva, and I. Trillas, "Composting winery waste: sludges and grape stalks," Bioresource Technology, vol. 95, no. 2, pp. 203-208, 2004.

[11] F. Hanafi, O. Assobhei, and M. Mountadar, "Detoxification and discoloration of Moroccan olive mill wastewater by electrocoagulation," Journal of Hazardous Materials, vol. 174, no. 1-3, pp. 807-812, 2010.

[12] N. Hytiris, I. E. Kapellakis, R. L. R. de, and K. P. Tsagarakis, "The potential use of olive mill sludge in solidification process," Resources, Conservation and Recycling, vol. 40, no. 2, pp. 129-139, 2004.

[13] M. Madani, M. Aliabadi, B. Nasernejad, R. K. Abdulrahman, M. Y. Kilic, and K. Kestioglu, "Treatment of olive mill wastewater using physico-chemical and Fenton processes," Desalination and Water Treatment, vol. 53, no. 8, pp. 20312040, 2015.

[14] M. Mosca, F. Cuomo, F. Lopez, G. Palumbo, G. Bufalo, and L. Ambrosone, "Adsorbent properties of olive mill wastes for chromate removal," Desalination and Water Treatment, vol. 54, no. 1, pp. 275-283, 2015.

[15] S. P. Tsonis, V. P. Tsola, and S. G. Grigoropoulos, "Systematic characterization and chemical treatment of olive oil mill wastewater," Toxicological and EnvironmentalChemistry, vol. 20-21, no. 1, pp. 437-457, 1989.

[16] A. Zirehpour, A. Rahimpour, and M. Jahanshahi, "The filtration performance and efficiency of olive mill wastewater treatment by integrated membrane process," Desalination and Water Treatment, vol. 53, no. 5, pp. 1254-1262, 2015.

[17] L. E. Fels, M. Hafidi, and Y. Ouhdouch, "Date palm and the activated sludge co-composting actinobacteria sanitization potential," Environmental Technology, vol. 37, no. 1, pp. 129-135, 2016.

[18] S. Hachicha, F. Sallemi, K. Medhioub, R. Hachicha, and E. Ammar, "Quality assessment of composts prepared with olive mill wastewater and agricultural wastes," Waste Management, vol. 28, no. 12, pp. 2593-2603, 2008.

[19] S. Masmoudi, R. Jarboui, H. E. Feki, T. Gea, K. Medhioub, and E. Ammar, "Characterization of olive mill wastes composts and their humic acids: stability assessment within different particle size fractions," Environmental Technology, vol. 34, no. 6, pp. 787-797, 2013.

[20] C. Paredes, A. Roig, M. P. Bernal, M. A. Sánchez-Monedero, and J. Cegarra, "Evolution of organic matter and nitrogen during co-composting of olive mill wastewater with solid organic wastes," Biology and Fertility of Soils, vol. 32, no. 3, pp. 222-227, 2000.

[21] L. Zhang and X. Sun, "Influence of bulking agents on physical, chemical, and microbiological properties during the two-stage composting of green waste," Waste Management, vol. 48, pp. 115-126, 2016.

[22] L. Zhang and X. Sun, "Changes in physical, chemical, and microbiological properties during the two-stage cocomposting of green waste with spent mushroom compost and biochar," Bioresource Technology, vol. 171, pp. 274-284, 2014.

[23] C. S. Akratos, A. G. Tekerlekopoulou, I. A. Vasiliadou, and D. V. Vayenas, "Chapter 8-Cocomposting of olive mill waste for the production of soil amendments," in Olive Mill Waste, C. M. Galanakis, Ed., pp. 161-182, Academic Press, Cambridge, MA, USA, 2017.

[24] S. Hachicha, M. Chtourou, K. Medhioub, and E. Ammar, "Compost of poultry manure and olive mill wastes as an alternative fertilizer," Agronomy for Sustainable Development, vol. 26, no. 2, pp. 135-142, 2006.
[25] F. Sellami, R. Jarboui, S. Hachicha, K. Medhioub, and E. Ammar, "Co-composting of oil exhausted olive-cake, poultry manure and industrial residues of agro-food activity for soil amendment," Bioresource Technology, vol. 99, no. 5, pp. 1177-1188, 2008.

[26] P. Proietti, R. Calisti, G. Gigliotti, L. Nasini, L. Regni, and A. Marchini, "Composting optimization: integrating cost analysis with the physical-chemical properties of materials to be composted," Journal of Cleaner Production, vol. 137, pp. 1086-1099, 2016.

[27] S. Hachicha, F. Sellami, J. Cegarra et al., "Biological activity during co-composting of sludge issued from the OMW evaporation ponds with poultry manure-physico-chemical characterization of the processed organic matter," Journal of Hazardous Materials, vol. 162, no. 1, pp. 402-409, 2009.

[28] N. Abid and S. Sayadi, "Detrimental effects of olive mill wastewater on the composting process of agricultural wastes," Waste Management, vol. 26, no. 10, pp. 1099-1107, 2006.

[29] I. Aviani, Y. Laor, S. Medina, A. Krassnovsky, and M. Raviv, "Co-composting of solid and liquid olive mill wastes: management aspects and the horticultural value of the resulting composts," Bioresource Technology, vol. 101, no. 17, pp. 6699-6706, 2010.

[30] Z. Majbar, Z. Rais, M. El Haji, M. B. Abbou, H. Bouka, and M. Nawdali, "Olive mill wastewater and wine by-products valorization by co-composting," Journal of Materials and Environmental Science, vol. 8, no. 9, pp. 3162-3167, 2017.

[31] K. Lahlou, M. Ben Abbou, Z. Majbar et al., "Recovery of sludge from the sewage treatment plant in the city of $\mathrm{Fez}$ (STEP) through the composting process," Journal of Materials and Environmental Sciences, vol. 8, no. 12, pp. 4582-4590, 2017.

[32] D. Raj and R. S. Antil, "Evaluation of maturity and stability parameters of composts prepared from agro-industrial wastes," Bioresource Technology, vol. 102, no. 3, pp. 28682873, 2011.

[33] W. Abid, E. Ammar, M. A. Triki, M. Ben Abbou, and M. El Haji, "Gestion et valorisation des margines par co compostage avec les déchets verts et amendements des sols agricoles pour l'amélioration des rendements," Brevet déposé à l'Office Marocain de la Propriété Industrielle et Commerciale, MA 20150445 A1, 2015.

[34] C. Paredes, M. P. Bernal, J. Cegarra, and A. Roig, "Biodegradation of olive mill wastewater sludge by its cocomposting with agricultural wastes," Bioresource Technology, vol. 85, no. 1, pp. 1-8, 2002.

[35] L. El Fels, M. Zamama, A. El Asli, and M. Hafidi, "Assessment of biotransformation of organic matter during co-composting of sewage sludge-lignocelullosic waste by chemical, FTIR analyses, and phytotoxicity tests," International Biodeterioration and Biodegradation, vol. 87, pp. 128-137, 2014.

[36] L. E. Fels, M. Zamama, A. Aguelmous et al., "Assessment of organo-mineral fraction during co-composting of sewage sludge-lignocellulosic waste by XRD and FTIR analysis," Moroccan Journal of Chemistry, vol. 5, no. 4, pp. 730-739, 2017.

[37] L. El Fels, F. Z. El Ouaqoudi, L. Lemee et al., "Identification and assay of microbial fatty acids during co-composting of active sewage sludge with palm waste by TMAHthermochemolysis coupled with GC-MS," Chemistry and Ecology, vol. 31, no. 1, pp. 64-76, 2015.

[38] L. Nasini, G. De Luca, A. Ricci et al., "Gas emissions during olive mill waste composting under static pile conditions," 
International Biodeterioration and Biodegradation, vol. 107, pp. 70-76, 2016.

[39] B. Soudi, "Le compostage des déchets des cultures sous serre et du fumier," Bullletin Mensuel d'Information et de Liaison du PNTTA, vol. 129, pp. 1-6, 2005.

[40] ISO 8633, Solid Fertilizers-Simple Samplingmethod for Small Lots, ISO, Geneva, Switzerland, 1992, https://www.iso.org/ standard/15994.html.

[41] International Organization for Standardization, ISO 10390Soil Quality-Determination of $\mathrm{pH}$, ISO, Geneva, Switzerland, 2005, https://www.iso.org/standard/40879.html.

[42] International Organization for Standardization, ISO 11265Soil Quality-Determination of the Specific Electrical Conductivity, ISO, Geneva, Switzerland, 1994, https://www.iso.org/ standard/19243.html.

[43] French Association for Standardization, Determination of Nitrogen Kjeldahl-Titrimetric Determination Method after Mineralization and Distillation, NF T90-110, French Association for Standardization, France, 1981.

[44] J. Rodier, B. Legube, N. Merlet, and R. Brunet, L'Analyse de l'Eau, Dunod, Paris, France, 9th edition, 2009, https:// www.fichier-pdf.fr/2012/12/08/1-analyse-de-l-eau-9e-editionentierement-mise-a-jour-jean-rodie/l-analyse-de-l-eau9e-edition-entierement-mise-a-jour-jean-rodie.pdf.

[45] NF T90-101, "Water quality-determination of chemical oxygen demand (COD)-qualité de l'eau," 2001, https://www. boutique.afnor.org/norme/nf-t90-101/qualite-de-l-eaudetermination-de-la-demande-chimique-en-oxygene-dco/ article/778836/fa111555.

[46] C. Tognetti, M. J. Mazzarino, and F. Laos, "Improving the quality of municipal organic waste compost," Bioresource Technology, vol. 98, no. 5, pp. 1067-1076, 2007.

[47] L. Baeta-Hall, M. CéuSàágua, M. Lourdes Bartolomeu, A. M. Anselmo, and M. Fernanda Rosa, "Bio-degradation of olive oil husks in composting aerated piles," Bioresource Technology, vol. 96, no. 1, pp. 69-78, 2005.

[48] B. Zenjari, H. El Hajjouji, G. AitBaddi et al., "Eliminating toxic compounds by composting olive mill wastewater-straw mixtures," Journal of Hazardous Materials, vol. 138, no. 3, pp. 433-437, 2006.

[49] S. Amir, M. Hafidi, G. Merlina, and J.-C. Revel, "Sequential extraction of heavy metals during composting of sewage sludge," Chemosphere, vol. 59, no. 6, pp. 801-810, 2005.

[50] C. Francou, Stabilisation de la Matière Organique au Cours du Compostage de Déchets Urbains: Influence de la Nature des Déchets et du Procédé de Compostage-Recherche d'indicateurs Pertinents, INAPG (AgroParisTech), Paris, France, 2003, https://pastel.archives-ouvertes.fr/pastel-00000788/.

[51] J. Singh and A. S. Kalamdhad, "Assessment of compost quality in agitated pile composting of water hyacinth collected from different sources," International Journal of Recycling of Organic Waste in Agriculture, vol. 4, no. 3, pp. 175-183, 2015.

[52] NF U44-051, "Organic soil improvers-designations, specifications and marking," 2006, https://www.boutique.afnor.org/ standard/nf-u44-051/organic-soil-improvers-designationsspecifications-and-marking/article/686933/fa125064.

[53] J. A. Alburquerque, J. Gonzálvez, G. Tortosa, G. A. Baddi, and J. Cegarra, "Evaluation of "alperujo composting based on organic matter degradation, humification and compost quality," Biodegradation, vol. 20, no. 2, pp. 257-270, 2009.

[54] J. A. Alburquerque, J. Gonzálvez, D. García, and J. Cegarra, "Measuring detoxification and maturity in compost made from "alperujo," the solid by-product of extracting olive oil by the two-phase centrifugation system," Chemosphere, vol. 64, no. 3, pp. 470-477, 2006.

[55] A. K. M. Muktadirul Bari Chowdhury, C. S. Akratos, D. V. Vayenas, and S. Pavlou, "Olive mill waste composting: a review," International Biodeterioration and Biodegradation, vol. 85, pp. 108-119, 2013.

[56] F. Sellami, S. Hachicha, M. Chtourou, K. Medhioub, and E. Ammar, "Bioconversion of wastes from the olive oil and confectionary industries: spectroscopic study of humic acids," EnvironmentalTechnology, vol. 28, no. 11, pp. 1285-1298, 2007.

[57] K. Lasaridi, I. Protopapa, M. Kotsou, G. Pilidis, T. Manios, and A. Kyriacou, "Quality assessment of composts in the Greek market: the need for standards and quality assurance," Journal of Environmental Management, vol. 80, no. 1, pp. 58-65, 2006.

[58] M. Chikae, R. Ikeda, K. Kerman, Y. Morita, and E. Tamiya, "Estimation of maturity of compost from food wastes and agro-residues by multiple regression analysis," Bioresource Technology, vol. 97, no. 16, pp. 1979-1985, 2006. 

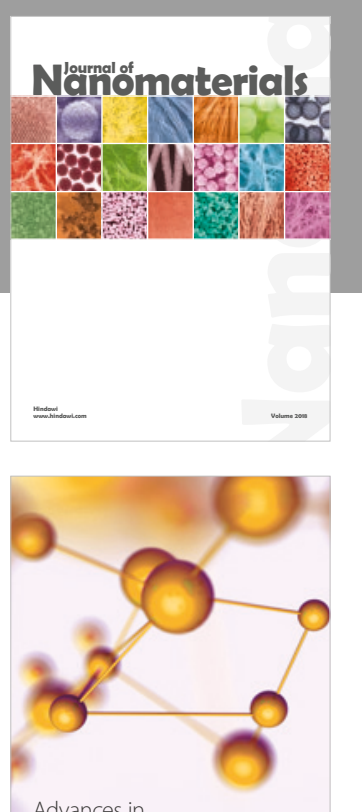

Physical Chemistry
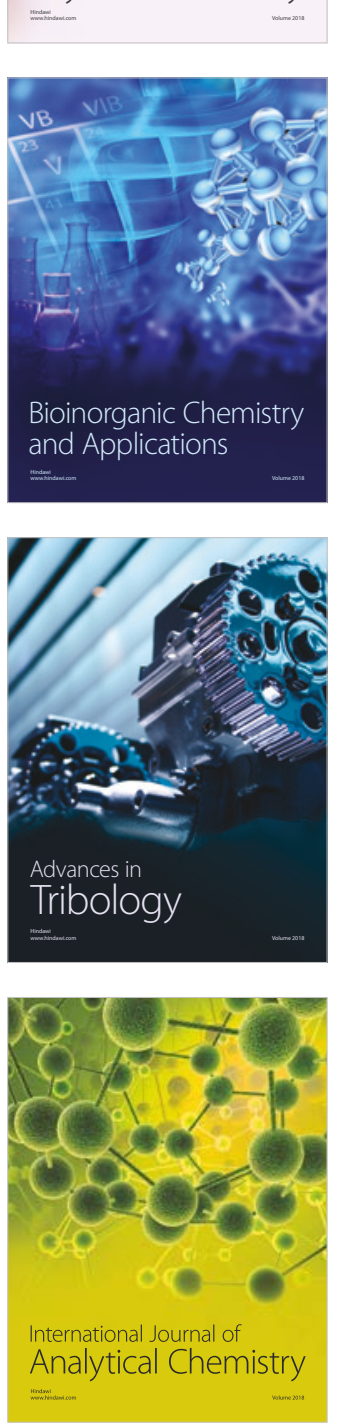

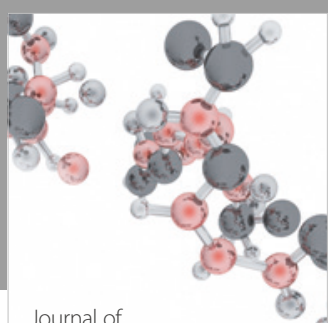

Analytical Methods in Chemistry

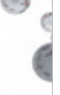

\section{The Scientific World Journal}
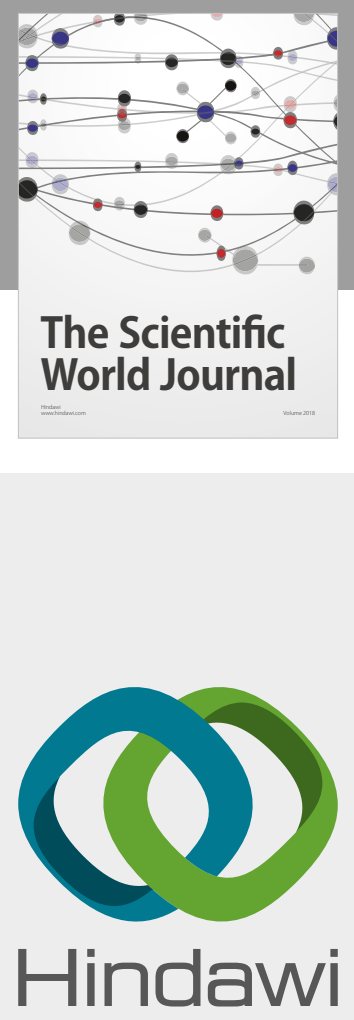

Submit your manuscripts at

www.hindawi.com
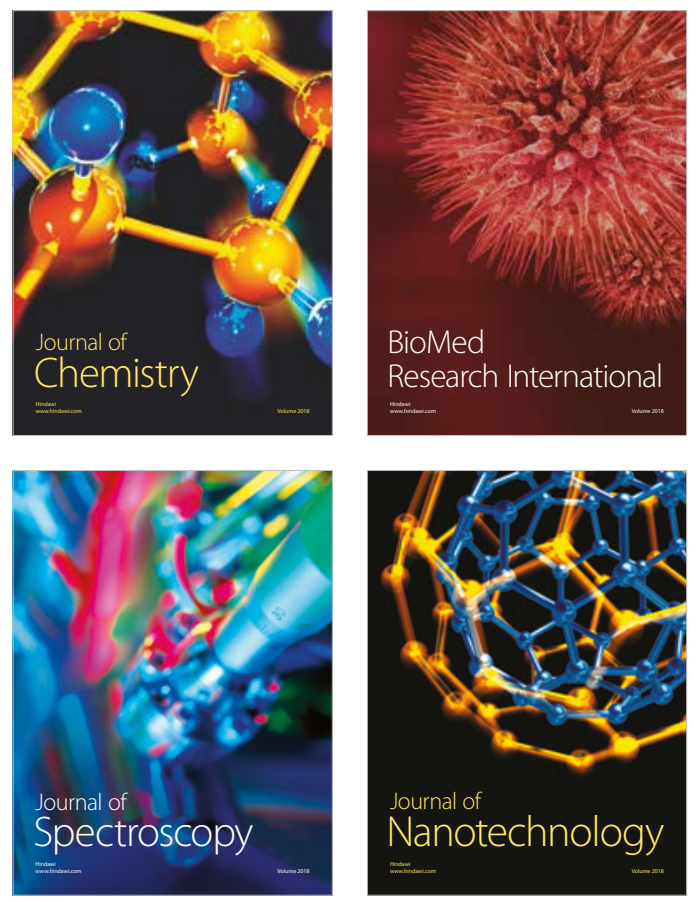

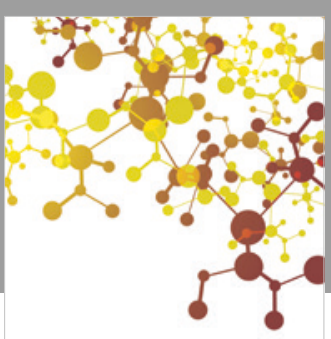

Apurnal of
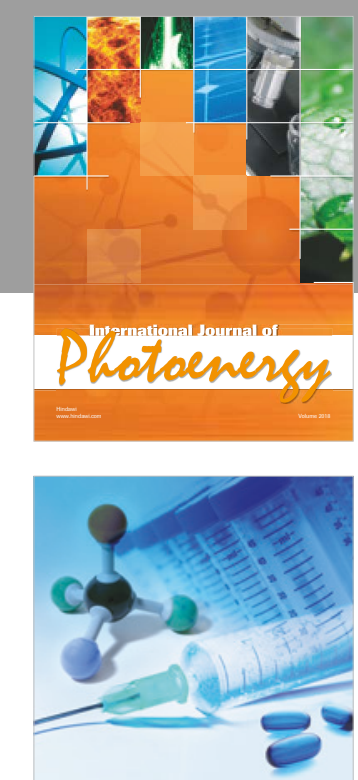

International Journal of Medicinal Chemistry
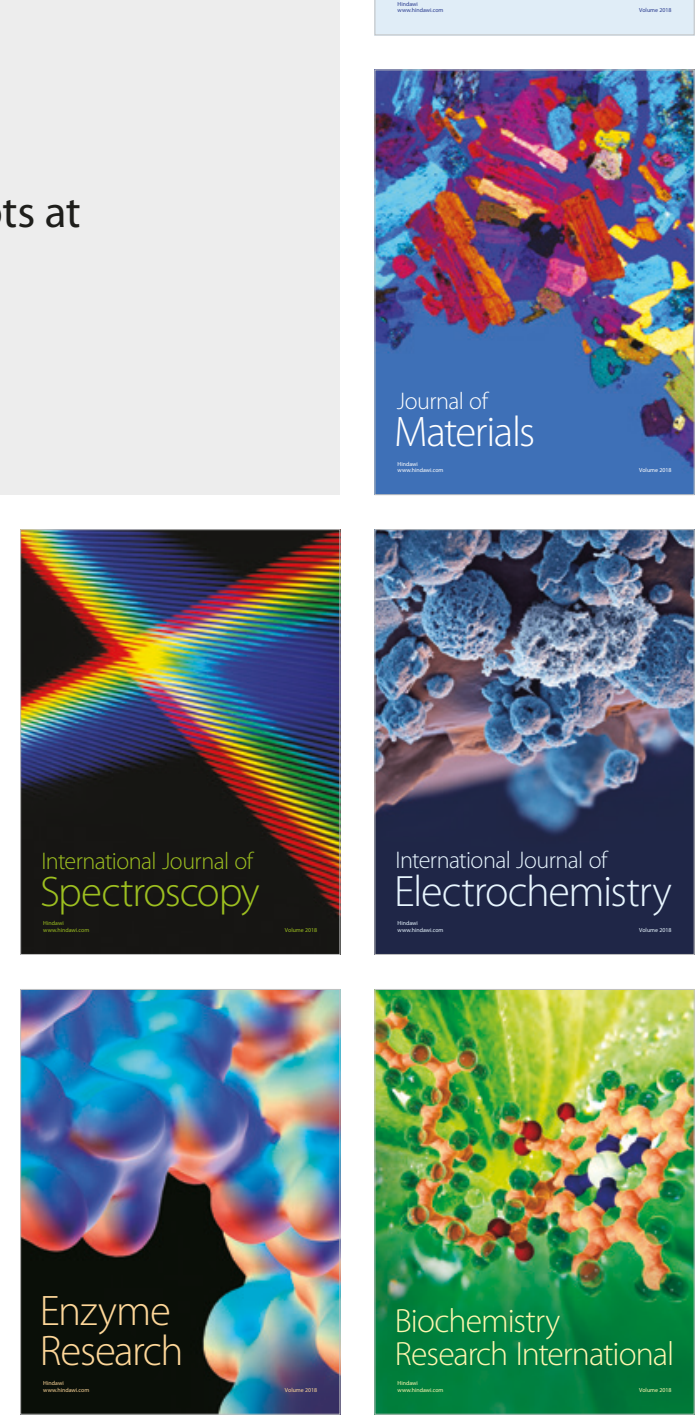
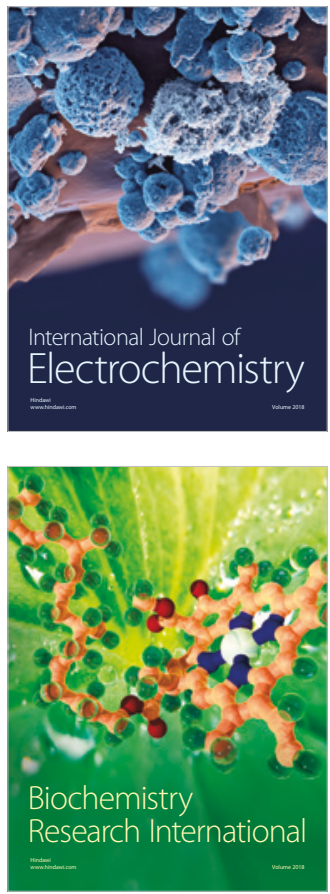